\title{
The responsibility of the regional heads against the management of regional finances
}

\author{
Dani Sintara $^{*}$ and Faisal Akbar Nasution \\ Doctoral Program in Law, Graduate School, Universitas Sumatera Utara, Medan, \\ Indonesia
}

\begin{abstract}
In administering governance, Regional Heads are given an authority to manage the local finances independently. This authority is regulated in Law Number 9 of 2015 and Government Regulation Number 3 of 2007. Accountability of Regional Heads is a form of a democratic government. In a democratic government, the government has limited power and is not justified to act arbitrarily against its citizens. In reality, the implementation of the accountability is often the result of a political compromise. Political compromises occur due to the behavior of the political elite and the weakness of the existing legislation. This weakness relates to the mechanism of the accountability against the management of regional finances which opens an opportunity between the Regional Heads and the Regional House of Representatives (DPRD) to conduct a negative relationship. The political compromises in the accountability of the Regional Heads have had a negative impact on the local governance. Whereas, the purpose of implementing a regional autonomy is to improve the quality of justice, democracy and prosperity. Therefore, before the DPRD rejects the accountability of the Regional Heads, it must first be tested in the Supreme Court.
\end{abstract}

\section{Introduction}

The State of Indonesia is a unitary state in the form of a republic. It is stipulated in Article 1 Paragraph (1) of the 1945 Constitution. As a unitary state, all power/authorities and responsibilities of governance in order to realize the prosperity and survival of the nation is under the control of a centralized power in the central government. ${ }^{[1]}$

In fact, the implementation of power centralization provides efficiency in decision making. ${ }^{[2]}$ Yet, the founders of the state are aware of the natural conditions living in the diverse Indonesian society. So the type of government in Indonesia is based on the powersharing system between the central government and community groups in the region ${ }^{[3]}$. This will, in the end, create the Regional Government based on the decentralization system as regulated in Article 18 of the 1945 Constitution.

Technically, decentralization gives rise to arguments that can support the smooth running of local government, namely: the people of a region are obliged to advance the region, are more closely related and more familiar with the needs of the region. ${ }^{[4]}$

* Corresponding author: danisintara@yahoo.co.id 
In implementing Regional Governance, the Regional Head will be given an authority to organize things including the management of regional finances independently because regional autonomy generated through a devolution of power will have a positive effect when given financial management autonomy. ${ }^{[5]}$

However, although the regions are given the authority in financial management, the implementation must be accompanied by accountability. The responsibility should certainly goes to the Regional Head, given that the accountability of the Regional Head in the financial management is a manifestation of a democratic government. Without such a means, the meaning of democracy is lost because the government has turned into a ruler who does not need to give accountability.

The accountability of the Regional Head against the management of regional finances is intended to determine the level of success and failure that occurs after the regional planning is made and implemented. That is why responsibility is required as a form of control on the implementation of the Local Government. The goal is to get feedback for improvement, if there are errors or aberrations, before they become worse and more difficult to fix.

In reality, the accountability of the Regional Head against the financial management has given rise to an assumption: the accountability of the Regional Head in the management of regional finances is a political compromise. The process is full of interesting nuances of political interest among existing political institutions in the region.

Before the enactment of Law Number 9 of 2015 on Regional Government, the regulation governing the Regional Government is regulated in Law Number 22 of 1999. Both Laws bring different consequences in the implementation of the Regional Head's accountability to the financial management area.

At the time of the enactment of Law Number 22 of 1999, the Regional Head is supervised by Regional House of Representatives (DPRD). It proved that the Regional Head is responsible to the DPRD. The Regional Head is elected and determined by the DPRD and authorized by the President. In carrying out the duties and obligations as the Regional Head of the Governor shall be responsible to the Provincial DPRD, and in its capacity as the government representation, Governor is under supervision and responsible to the President. In carrying out its duties and authority as Regional Head, Regent/Major is responsible to the Regency/Municipal DPRD. After the enactment of Law Number 9 of 2015, the Regional Head is not accountable to the DPRD, because the Regional Head is directly elected by the voters in that area in a democratic manner. The relationship between the Regional Head and the DPRD is an equal as partner and working relationship. Equal position means that among that both local government institutions have the same position and parallel or not mutually supervisory. ${ }^{[6]}$

Furthermore, in relevancy to the responsibility of the Regional Head on the management of regional finances, in Law Number 22 of 1999, the Regional Head is obliged to submit the Accountability Report (LPj) on the management of regional finances to the DPRD. If the DPRD assesses that the Head of Regional Head is not in accordance with the Regional Strategic Plan (Renstra) then the DPRD can reject it. The DPRD can put forward the dismissal of the Regional Head in case of $\mathrm{LPj}$ is twice rejected. The juridical consequences is placed the Head of Region under supervision of the DPRD, when it should be between the Head of Regional and DPRD are equal partners in the implementation of Regional Government.

After the enactment of Law Number 9 of 2015, the Regional Head no longer gives LPj to DPRD. However, it is only limited to provide the information submitted through Accountability Report (LKPj). With respect to LKPj of the Regional Head, in case the DPRD judges it is not in accordance with RKPD, the DPRD cannot refuse it, but only gives a recommendation to the Head of Region for improvement. 
However, in the implementation of Law Number 9 of 2015, even though the DPRD can no longer refuse LKPj of the Regional Head, but with the rights attached to the DPRD in carrying out its supervisory functions, namely the right of interpellation, the right of inquiry and the petition rights allow the DPRD to investigate LKPj of the Regional Head. Even suggested the dismissal of the Regional Head. In the implementation of the Regional Head politically hosted by the power of DPRD.

The political compromise will have a devastating effect on the implementation of Regional Government. Whereas the purpose of regional autonomy implementation is to improve the quality of justice, democracy and prosperity for all elements of a diverse nation within the Unitary State of the Republic of Indonesia.

This study was intended to see the accountability of the Regional Head against the management of regional finances.

\section{Problem}

The problem of this study was: How does the accountability of the Regional Head against the management of regional finances work?

\section{Research methods}

The type of research conducted is standard legal research. This study is only aimed at normative regulations. This study is closely related to the library because the standard legal research requires data that is secondary to the library.

The nature of the research is descriptive analytical. This means that this study illustrates how a legal provision in the context of legal theories in the presentation describes the various issues related to the accountability of the regional head on the management of regional finances.

The data was secondary data consisting of (a) primary legal materials in the form of legislation, (b) secondary law materials in the form of writings, both books and articles containing comment or analysis related to the subject matter, and (c) tertiary legal materials in the form of dictionaries. The data was collected using literature reviews and document analysis for further analyzed using a qualitative method based on a logic deductive thinking.

\section{Discussions}

\subsection{Liability mechanism of the management of regional finances}

In the Law on State Finances, there is an affirmation on financial management saying that the power of state financial management is the power of the Government. The power of state financial management from the President is partly handed over to the Governor/Regent/Mayor as head of the Local Government to manage local finances. This provision certainly has implications for the regional financial management arrangements where the Governor/Regent/Mayor is responsible for the management of regional finances. ${ }^{[7]}$

The accountability of the Regional Head against the management of local finances might come in the form of responsibility against the use of Regional Revenue and Expenditure Budgets (APBD). This responsibility is included in the Liability Report (LKPJ) and presented to the Regional House of Representatives (DPRD) to be discussed 
and heard by each political faction. Then, a joint discussion with the Regional Work Units (SKPD) is conducted before a conclusion is made.

If the accountability mechanism of the local financial management is further elaborated, then it all starts with the Heads of SKPD as the budget users organizing the accounting of financial transactions, assets, and debts, which are under their responsibility.

The accounting report clarifies the recording/administering financial transactions in SKPD working areas in order to prepare financial statements. The financial statements consist of budget realization reports, balance sheets, and notes to the financial statements submitted to the Regional Head through the Regional Financial Management Officers (PPKD). Heads of SKPD as users of budget/users of goods give a statement that the management of regional finances under their responsibility has been conducted based on the internal control system which is adequate and practiced in accordance with the provisions of the legislation. ${ }^{[8]}$

The financial statements will be attached with the performance overview report and the Regional Financial Institution/Company report. The performance overview report is compiled from the summary of the accountability report of the Regional Heads. The financial report of the Regional Government above is prepared based on SKPD's financial report and submitted to the Regional Head as the implementation of the accountability of the management of regional finances. Then the Regional Head submits the Drafts of Local Regulations in the form of the implementation accountability of APBD to DPRD through financial reports which have been examined by the Financial Audit Board (BPK). ${ }^{[9]}$

The Regional Head's LKPJ is presented in a plenary session of DPRD and then discussed internally by DPRD. Based on the discussion, DPRD determines a decision no later than 30 (thirty) days after the LKPJ is received. The decision of DPRD will be submitted to the Regional Head in a special plenary meeting as a recommendation to the Regional Head for improvement in the implementation of Regional Government in the future. If the LKPJ has not been addressed by DPRD within 30 (thirty) days after the report is accepted, it is considered that there is no recommendation for improvement needs to be performed. ${ }^{[10]}$

It can be said that in the management of accountable and transparent local finances, the Regional Government must submit accountability in the form of financial statements. The financial statements are prepared in accordance with government accounting standards. Before the financial statements are reported to the public through DPRD, they need to be audited by BPK.

\subsection{Responsibility of the management of regional finances as a result of political compromises.}

Power tends to corrupt and absolute power corrupts absolutely. The statement that Lord Acton, a British scholar who lived between 1838 and 1902, said was originally a mere hypothesis. The hypothesis that eventually became undeniable destiny in a long history of power. ${ }^{[11]}$

Furthermore, what is the relationship between the sentence expressed by Lord Acton and the responsibility of the Regional Head against the management of regional finances?

Law Number 9 of 2015 on Second Amendment to Law Number 23 of 2014 on Local Government hereinafter abbreviated as UU PEMDA and Government Regulation Number 3 of 2007 state that DPRD only gives recommendation to LKPJ submitted by the Regional Head. In other words, DPRD can no longer reject the accountability of the Regional Head against the implementation of the regional financial management.

In fact, although it is impossible for DPRD to reject LKPJ, with the rights attached to the DPRD, there is a great possibility for DPRD to take action if LPKJ is considered to 
violate the benchmark of the Regional Development Plan (RKPD) conducted under the supervisory function of DPRD. This happens in connection with the operationalization of the theory of checks and balances in order to create a direct supervision of one branch of government against other branches. ${ }^{[12]}$

The supervisory function of DPRD on the implementation of the management of local finances can be done through the rights of DPRD: First, the right of interpellation, that is the right of DPRD to request a clarification to the Regional Head about an important and strategic Local Government policy that has a wide impact on the life of the community, region and state which is assumed to violate the laws and regulations.

Second, the inquiry right, that is the right of DPRD to investigate a particular policy of the Regional Head that is important and strategic and has a wide impact on the life of the community, region and state which is assumed to violate the laws and regulations. Third, the petition right, that is the right of DPRD to express an opinion toward the policy of the Regional Head or about extraordinary events occurring in the region accompanied by a recommendation for completion or as a follow-up to the implementation of the rights of interpellation and inquiry. ${ }^{[13]}$

The rights attached to DPRD can result in the impeachment of the Regional Heads. However, the supervision carried out by DPRD against the Regional Government is not balanced with the supervision carried out on the institution of DPRD itself. Until now there is no specific regulation governing the control of DPRD.

Consequently, in carrying out his/her accountability against the management of regional finances, the Regional Head often becomes hostage to the power and/or political interests existing in DPRD. If the Regional Head comes from the minority Political Party or was an independent candidate, then in the process of accountability, he/she will get much pressure from the DPRD. Whereas, if the Regional Head comes from the majority party in DPRD, it will be difficult for DPRD to supervise the management of the regional finances.

As such, the Regional Head's accountability against the management of regional finances will result in a political compromise between DPRD and the Regional Head. In the end, this will bring about a bad impact on the implementation of Regional Government as the purpose of regional autonomy implementation, namely to improve the welfare of the community in the region, will not be fully implemented.

The above opinion is consistent with what J. Kaloh put forward: The legislative and executive relationship in a region can lead to a negative one-way relationship when regional executives and legislators collaborate in governance and collectively conceal the collaboration from the public. ${ }^{[14]}$

Therefore, there must be an external control of DPRD which will be a medium to accommodate, channel and fight for the complaints of the community toward the actions taken by DPRD members and its institution. In order to implement the check and balances system, in the future the Local Government should also be given an authority to conduct supervision on DPRD.

The rights that attached to the DPRD, namely the right of interpellation, the right of inquiry and the right of petition is in order to oversee the implementation of Regional Government. It is intended that the administration of the government is no despotism occurs.

However, to maintain the balance in the implementation of the Regional Government, especially in accountability of the Regional Head to the management of regional finance, so that the Regional Head politically hosted by the power of DPRD, there is ideal mechanism stages shall be done. Firstly, after the Head of Region submits LKPj to the DPRD, the DPRD shall discuss whether the LKPJ is in accordance with the RKPD or not. In case it is not yet appropriate, the DPRD shall give a recommendation to the Regional Head for improvement. In conducting the discussion, the DPRD must provide space for the society to 
participate in issuing opinions as a manifestation of civil and political rights owned by the society. Secondly, if the recommendation given by DPRD has been improved by the Regional Head and in accordance with the RKPD, then the LKPj is considered to be completed. Third, if the recommendation given by DPRD has not been or has been improved by the Regional Head but still not in accordance with RKPD, the DPRD then uses its supervisory function through the rights attached to it, namely: interpellation rights, the right of inquiry and petition rights. Fourth, the results of the DPRD supervision function were brought to the Supreme Court for testing, wheter the accountability of the Regional Head to the management of regional finances in accordance with RKPD or not. Fifth, the Supreme Court as an institution that has the authority as the final decision against the potential responsibility of the Regional Head whether has been in accordance with the RKPD or not.

\subsection{Comparative law system approach to accountability of the management of local finances.}

From the legal system comparison view, especially the civil law and common law systems related to the Legal Institutions, there is no such a thing as legislative tradition in common law that seeks to amend or fix the law through legislators. This is totally different from what happens in civil law. Therefore, a significant historical fact is that the common law has been developed within and by the Court to give a legal status to the decision made by the Judge. While the civil law is formulated, compiled and improved and then codified and given the legal power by the Legislators. Therefore, within the common law jurisdiction, in relation to the legal institutions, the typical things are the beliefs, the principles of error, and judgment. While in civil law jurisdiction, there is a strong tendency towards formalism and rules that protect moral integrity. ${ }^{[15]}$

In conclusion, the civil law system promotes legal positivism. Legal positivism has several meanings. Most of its supporters adhere to 2 (two) basic propositions: First, the definition of law should not depend on the question of moral validity. Second, the law should only be identified according to concrete formal provisions such as legislation. H.L.A. Hart basically states that law is a human command and there is no need for a relationship between the law and morality. ${ }^{[16]}$

Therefore, the political compromises between the Regional Head and DPRD in relation to the management accountability of regional finances cannot be separated from formal procedural errors that exist in the legislation. The legislation established by the legislature provides an opportunity for political compromises, i.e. the accountability of the Regional Head against the management of regional finances cannot be rejected by DPRD. However, with the existing authority in DPRD (supervisory function), DPRD can give pressure to the Regional Head so that he/she will inevitably have to collude with DPRD by ignoring the moral responsibility.

In the civil law system adopted by the Indonesia (prioritizing legal positivism), there is no obligation to be morally responsible. The most important thing is that everything should be done in accordance with the laws and regulations even if they are contrary to the sense of justice in the society. Because one characteristic of legal positivism is: there is no need for a relationship between the law and morality.

Should it happen in a country with the common law system, the Regional Head should not worry about getting a pressure from the DPRD because the measure does not refer to the formal procedure contained in the legislation, but it is the verdict of the Judge that decides whether or not the responsibility of the Regional Head against the management of regional finances has met the ideals of the regional autonomy. 


\section{Conclusions}

\subsection{Summary}

In principle, the accountability of the Regional Head to the management of regional finance is a manifestation of a democratic government. Because without accountability then the meaning of democracy disappears because the government has turned into a ruler who does not need to give accountability. This is deemed necessary because the identity of constitutional democracy is a government that is limited its power from despotism. However, in its application the accountability mechanism of the Regional Head's management of regional finances is currently based on the political interests of the existing political institutions in the region. As a result, the purpose of the implementation of regional autonomy is not achieved, one of which is to provide a better prosperity for the existing communities in the region. The political compromises amongst the political institutions in the region are caused by the disproportion of power between the DPRD and the Regional Head.

\subsection{Suggestions}

It is recommended that the mechanism of accountability of the Head of Region towards the management of regional finances is implemented by giving space for the society. The provision of space for the society is to convey his opinion in order to conduct a joint discussion of LKPj. In case the LKPj is inconsistent with the RKPD, then the DPRD recommends the Regional Head for improvement. If the Head of Region has not made any improvements, or has made improvements but still not in accordance with RKPD, the DPRD shall use its supervisory function through interpellation rights, inquiry rights and petition rights. Then the result of the DPRD oversight function is tested in the Supreme Court as the authorized institution as the final decision whether the LKPj has been in accordance with RKPD or not. Besides, the Regional Head must also have the authority to supervise the performance of DPRD in order to check and balances system in the implementation of the Local Government is running well.

\section{References}

1. T. Triwulan Tutik, Pokok-pokok hukum tata negara, (Prestasi Pustaka, Jakarta, 2006).

2. F. Akbar Nasution, Dimensi hukum dalam pemerintahan daerah, (Pustaka Bangsa Press, Medan, 2003).

3. K. Marijan, Sistem politik Indonesia, konsolidasi demokrasi pasca orde baru, (Kencana Prenada Media Group, Jakarta, 2010).

4. F. Akbar Nasution, Pemerintahan daerah dan sumber-sumber asli pendapatan daerah, (PT Sofmedia, Medan, 2009).

5. C.E. Kaunang, A.T. Naukoko, A.T. Londa, Analisis kinerja pengelolaan keuangan daerah di era otonomi daerah: Studi pada kota Manado (Tahun 2010-2014), Jurnal Berkala Ilmiah Efisiensi, 16, 02 (2016).

6. B. N. Marbun, DPRD dan Otonomi Daerah Setelah Amandemen UUD 1945 dan UU Otonomi Daerah 2004, (Pustaka Sinar Harapan, Jakarta, 2005).

7. A. Syafrudin, Kapita selekta hakikat otonomi dan desentralisasi dalam pembangunan daerah, (Citra Media, Yogyakarta, 2006). 
8. A. Yani, Hubungan keuangan antara pemerintah pusat dan daerah di Indonesia, (PT Raja Grafndo Persada, Jakarta, 2008).

9. A. Yani, Hubungan keuangan antara pemerintah pusat dan daerah di Indonesia, (PT Raja Grafndo Persada, Jakarta, 2008).

10. S. Sunaryo, Hukum pemerintahan daerah di Indonesia, (Sinar Grafika, Jakarta, 2008).

11. D. Thaib, Teori dan hukum konstitusi, (PT Raja Grafindo Persada, Jakarta, 2003).

12. M. Fuady, Teori negara hukum modern, (PT Refika Aditama, Jakarta, 2009).

13. H. A W. Widjaja, Penyelenggaraan otonomi di Indonesia, (PT Raja Grafindo Persada, Jakarta, 2008).

14. J. Kaloh, Mencari bentuk otonomi daerah, (Penerbit Rineka Cipta, Jakarta, 2002).

15. P. de Cruz, Perbandingan sistem hukum common law, civil law and socialist law, (Nusa Media dan Diadit Media, Bandung dan Jakarta, 2016).

16. W. Menski, Perbandingan hukum dalam konteks global sistem Eropa, Asia dan Afrika, (Nusa Media, Bandung, (2016). 